
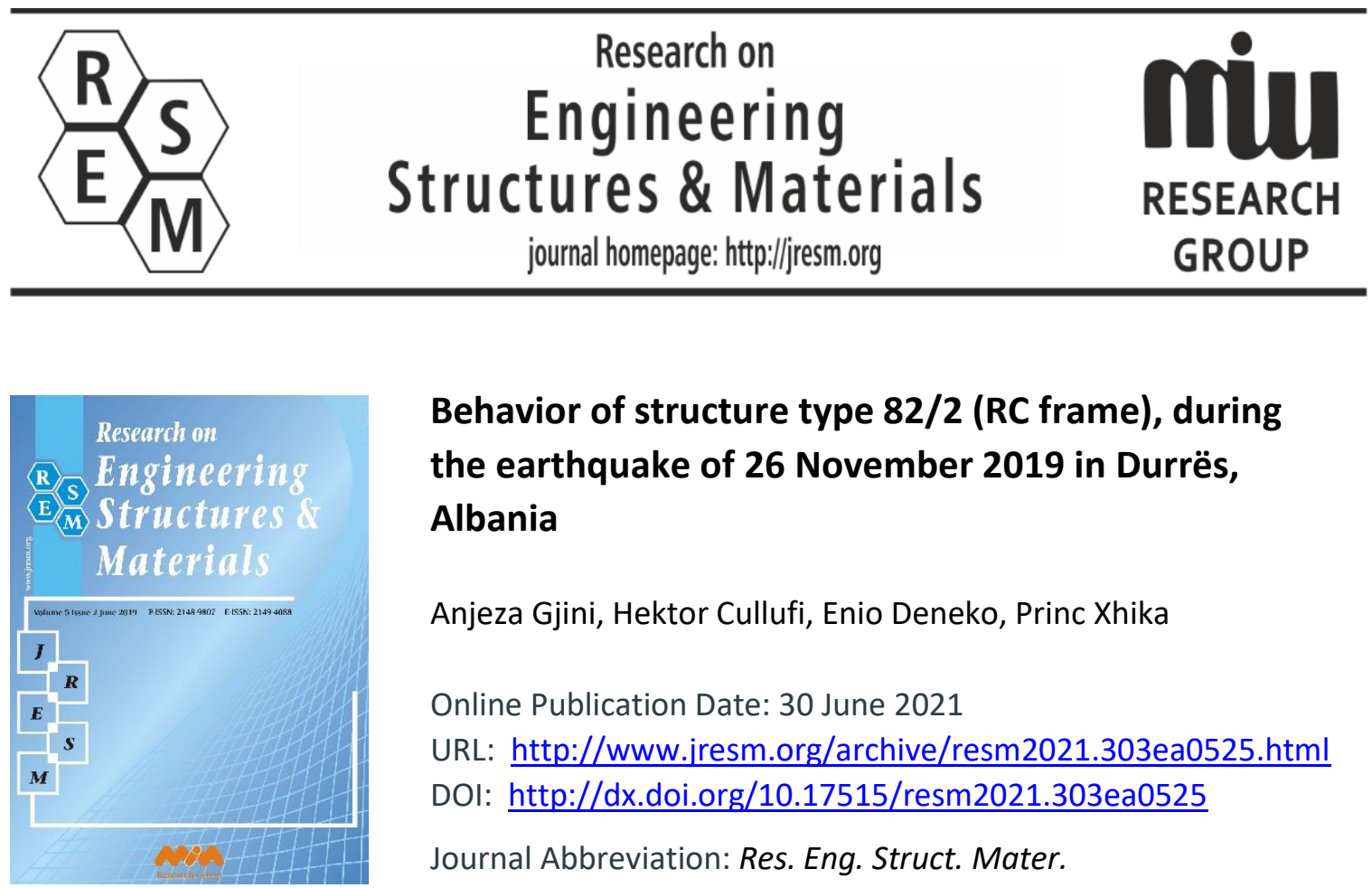

\title{
Behavior of structure type $82 / 2$ (RC frame), during the earthquake of 26 November 2019 in Durrës, Albania
}

Anjeza Gjini, Hektor Cullufi, Enio Deneko, Princ Xhika

Online Publication Date: 30 June 2021

URL: http://www.jresm.org/archive/resm2021.303ea0525.html

DOI: http://dx.doi.org/10.17515/resm2021.303ea0525

Journal Abbreviation: Res. Eng. Struct. Mater.

\section{To cite this article}

Gjini A, Cullufi H, Deneko E, Xhika P. Behavior of structure type 82/2 (RC frame), during the earthquake of 26 November 2019 in Durrës, Albania. Res. Eng. Struct. Mater., 2021; 7(4):

595-615.

\section{Disclaimer}

All the opinions and statements expressed in the papers are on the responsibility of author(s) and are not to be regarded as those of the journal of Research on Engineering Structures and Materials (RESM) organization or related parties. The publishers make no warranty, explicit or implied, or make any representation with respect to the contents of any article will be complete or accurate or up to date. The accuracy of any instructions, equations, or other information should be independently verified. The publisher and related parties shall not be liable for any loss, actions, claims, proceedings, demand or costs or damages whatsoever or howsoever caused arising directly or indirectly in connection with use of the information given in the journal or related means.

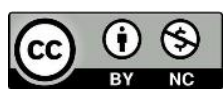

Published articles are freely available to users under the terms of Creative Commons Attribution - NonCommercial 4.0 International Public License, as currently displayed at here (the "CC BY - NC"). 


\title{
Research on Engineering Structures \& Materials
}

journal homepage: http://jresm.org

Research Article

\section{Behavior of structure type 82/2 (RC frame), during the earthquake of 26 November 2019 in Durrës, Albania}

\author{
Anjeza Gjini*1,a, Hektor Cullufi'1,b, Enio Deneko ${ }^{1, c}$, Princ Xhika²,d \\ ${ }^{1}$ Faculty of Civil Engineering, Polytechnic University of Tirana, Albania \\ ${ }^{2}$ Structural Engineer, Kastrati Group, Tirana, Albania
}

\begin{tabular}{l} 
Article Info \\
Article history: \\
Received 25 May 2021 \\
Revised 21 Jun 2021 \\
Accepted 28 Jun 2021 \\
\hline
\end{tabular}

Keywords:

Structure Type 82/2; Seismic events; Pushover analysis

\section{Abstract}

On November 26,2019 , an earthquake with magnitude $\mathrm{Mw}=6.4$ occurred in the city of Durrës, with epicenter about $16 \mathrm{~km}$ southwest of Mamurras. This seismic event caused 51 loss of life, hundreds injured and hundreds of damaged buildings. One of the typified structures, identified by the authors with the most cases of damage or even collapse, is the structure Type no. 82/2 built in some areas of the city of Durrës, in the period 1983-1993. The purpose of this study is to analyze the behavior of this type of structure during seismic loading (for two cases, five and six storey, from the same typology), using the non-linear static procedure (Pushover). The obtained results are compared with the damages recorded in the field for these buildings, concluding with their main causes. According to this study it appears that the main cause of failures occurred in this type of building is the reduction of the reinforcement amount from the ground floor to the first floor by $35.5 \%$ and percentage of reinforcement required for the given section exceeds the requirements of design standards (Eurocode- 2 and KTP-2-89) by around 30\%. Also on these failures contribute the low strength of concrete used in construction of some of these buildings (the compressive strength results $50 \%$ less than required) and the use of smooth rebar.

(C) 2021 MIM Research Group. All rights reserved.

\section{Introduction}

Durrës is one of the oldest cities in Albania (known as "Dyrrahum"), with a history of over 2500 years. The region of Durrës is subjected to several strong earthquakes (I0>VIII EMS98). It can be mentioned the earthquakes in 177 B.C., 334 or 345 A.C., 506, 1273, 1279, 1869 and 1870. The most significant earthquakes of the latest 30 years occur in September and November 2019, with the later one being the most devastating in Durres region. The earthquake of November 26, 2019 was a 6.4 magnitude earthquake, about $16 \mathrm{~km}$ off the coast of Mamurras at 3.54 CET [1]. The most affected area was Durrës and Thumanë, while significant damages were reported in Shijak, Kruja, Tirana, Kamza, Kavaja, Kurbin and Lezha, as well. The earthquake caused 51 fatalities, 913 people injured at least, and the damages of hundreds of buildings [2].

Previous studies are done after this earthquake to identify the damages and their causes for different types of structures. Referring to these studies, most of the inspected buildings sustained severe non-structural damage, because of the combination of flexible structural system and rigid infills. Also, there are some deficiencies in the current Albanian seismic code, that does not provide drift limitations for Damage Limit States. [3] Damage to infills was a widespread issue in Albania after the earthquake. The low lateral stiffness of wide beam - column connections was a likely contributor (in addition to other factors). [4] In

${ }^{*}$ Corresponding author: anjeza.gjini@fin.edu.al

${ }^{a}$ orcid.org/0000-0002-2258-5332; b orcid.org/0000-0001-5238-9992; c orcid.org/0000-0002-2029-2042;

d orcid.org/0000-0003-4295-2475

DOI: http://dx.doi.org/10.17515/resm2021.303ea0525

Res. Eng. Struct. Mat. Vol. 7 Iss. 4 (2021) 595-615 
the other hand, the URM structures built of masonry walls have been shown to have low seismic capacity. [5]

After this seismic event, the Construction Institute in cooperation with the academic staff of the Faculty of Civil Engineering in Tirana, organized a more detailed inspection of damaged buildings (in accordance with the DCM no.26, date 15.01.2020) [6] and identifying the extent of their damage. During this inspection in the city of Durrës, the authors (part of the inspection groups) found that one of the typologies with RC frame, named in the project as "Building type 82/2", has suffered significant damage. Two of these buildings collapsed during the November 26 earthquake. Others were assessed as severely damaged, due to significant damage to their structural elements.

Based on these findings and having the necessary data for the study, this article aims to analyze the behavior of building type 82/2, during the November 26 earthquake in Durres.

\section{Typologies of Constructions in Albania}

Buildings in Albania can be classified according to the construction period. Before 1952, the houses were 1-2 storey, built of brick or stone masonry. During the years 1952-1988 began the construction of the residential buildings according to the concept of "Typologies", in fulfillment of the communist ideology, to save construction time and reduce costs. Hence, from the 2-storey houses with a roof (type of 1958) it was transferred to 5-storey buildings (type of 1977) and further to those 6 floors (after 1982). The changes in the "Typology" of projects in different periods consisted not only in their functional and aesthetic requirements, but also in the structural aspect. Thus, from structures with the brick masonry (clay / silicate), the RC frame and the one with shear wall is further developed (after 1980). After 80', began the design and the construction of prefabricated buildings. They were quite prevalent because prefabricated panels permit a larger area of apartments. In1982 started the construction of 6-storey buildings with elevators and in 1988 the construction of those with shear wall. [7] [8].

After 1993 (in various literatures also refers to 1990, but in this article 1993 is taken as the year of change of the existing legal framework for construction, adapted to the basics of market economy), private investment began to develop in Albania, thus increasing the demand for high-buildings and premises with larger areas.

Referring to the study conducted by INSTAT (until 2011) [9] (Figure 1), it is noticed that 1-2 storey buildings occupy the highest percentage of constructions in the city of Durrës . From 1991 to 2011, the number of buildings more than 6 floors have increased by about $79 \%$ and occupy about $3.5 \%$ of the total number of constructions in this city.

Figure 2 shows that the number of construction permits approved for buildings more than 3 floors, throughout the territory of Albania, for the period 2016-2020 has increased 3.3 times and occupies about $22 \%$ of construction permits issued in this period (it is noted that the study refers only to residential buildings).

High-rise buildings ( $>6$ floors) designed mainly after 2001 are with RC frame system, with/without shear walls. 


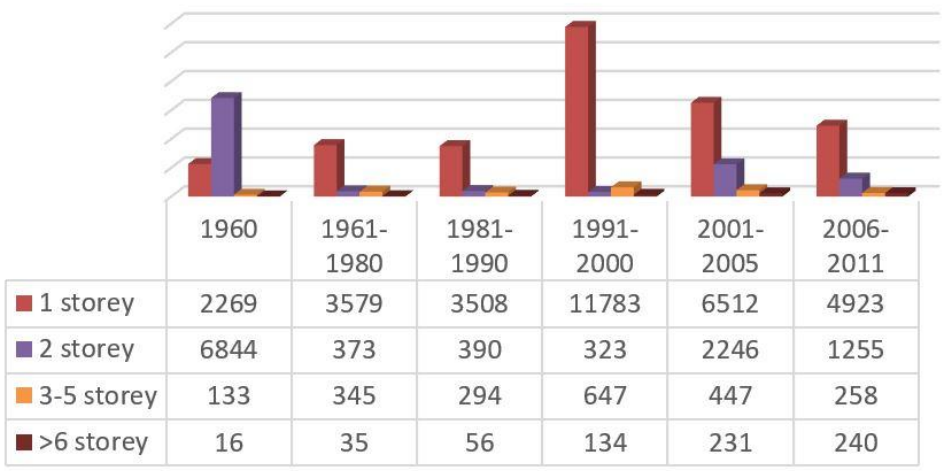

Fig. 1 Number of buildings by floors for the period 1960-2011, in the city of Durrës

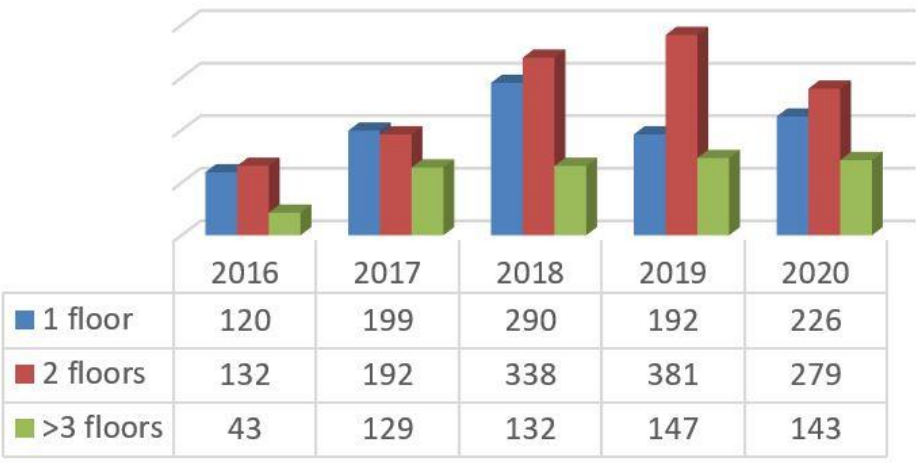

Fig. 2 Number of construction permits approved for the period 2016-2020 in the territory of Albania [9]

\section{November 26, 2019, Durrës Earthquake}

On September 21, 2019, in the city of Durrës was recorded the seismic event with magnitude $\mathrm{Mw}=5.6$, with epicenter $3 \mathrm{~km}$ southwest of Shijak, with a depth of $20 \mathrm{~km}$. The aftershocks continued for several weeks, until on November 26, 2019, the main shock was recorded with magnitude $\mathrm{Mw}=6.4$, with an epicenter about $15.6 \mathrm{~km}$ southwest of Mamurras [1]. 


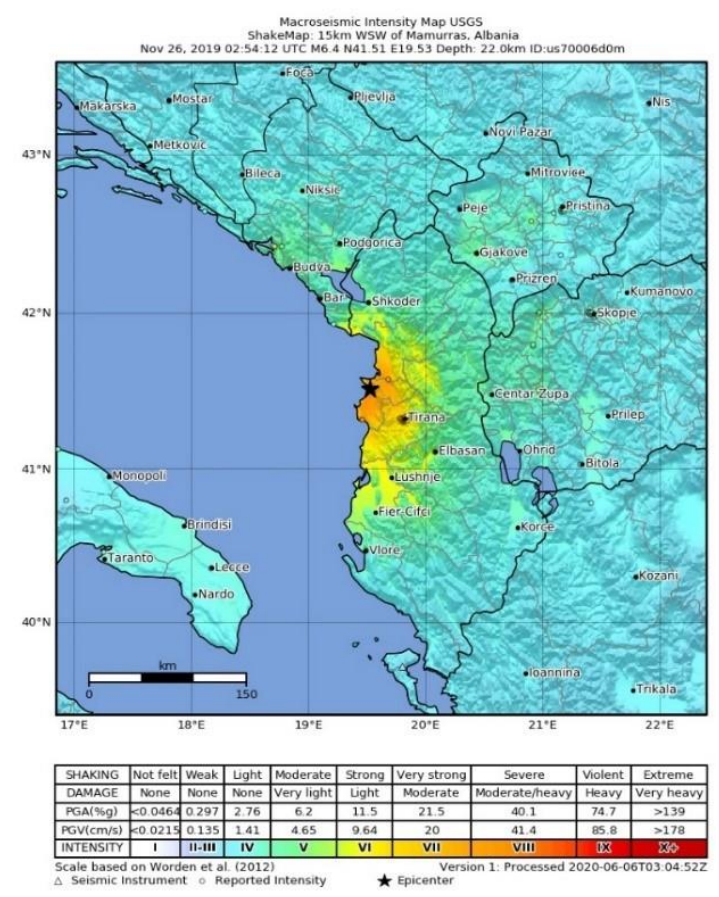

Fig. 3 Macroseismic Intensity Map [1]

Based on the microzoning map (MSK-64), the seismic intensity in the Durrës area is IX, so the seismicity coefficient takes the value $0.42 \mathrm{~g}$, for land category III.

The following figure shows the elastic spectra according to EC-8 [10] and KTP-2-89 (Technical Design Code of Albania, published in 1989) [11], as well as the real spectra according to the two main directions E-W and N-S recorded by Institute of Geosciences, Energy, Water and Environment (IGJEUM) at the Durrës station [12].

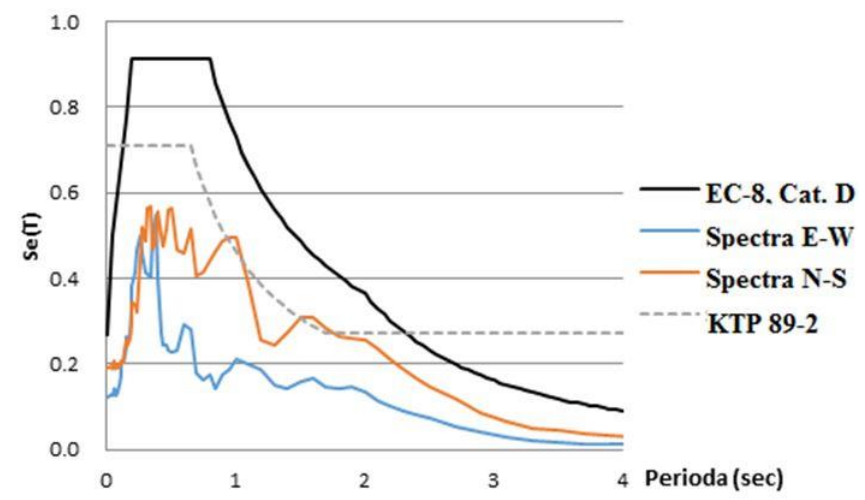

Fig. 4 Elastic spectra according to EC-8 (Cat.D, PGA 0.27g), KTP-2 (Cat.III, ao = 0.42g) and oscillation spectra recorded for both directions at Durrës station

As can be seen, the real spectra are within the elastic spectrum of Eurocode and almost within that of KTP. At certain points the spectrum in the N-S direction exceeds that of the KTP. This shows that the strongest waves are in this direction. [13] 


\section{Case Study}

The buildings taken in the study, located in the city of Durrës, are of the same typology, respectively type $82 / 2$ (year of design 1982), built in different periods. The structural design of the building Type 82/2, made available by the Central Technical Archive of Construction (AQTN) in Tirana (Figure 5), has been drafted by the Research and Design Institute No. 1 Tirana (ISP). Referring to this project, the building Type 82/2 is conceived as a structure with prefabricated reinforced concrete frames. This building is designed for areas with a seismic intensity IX (according the design notes). This project marks the beginning of the construction of RC frame structure, 5 -storey and 6-storey.

Research and Design Bureau (BSP) of the districts had the task of redesigning the project in accordance with the terrain, natural environment, climate, tradition (according to the technical notes of the project). The typology of buildings $82 / 2$ is constructed in Durrës according this design compiled by BSP. Referring to this re-designed project (Figures 6-8) some changes have been made regarding the structural project drafted by the ISP (Research and Design Institute, Tirana), namely:

- The 5 and 6 storey structure is designed as a monolithic reinforced concrete frame;

- The class of concrete has decreased, leading to increased amount of reinforcement of the columns. The studied buildings were constructed according to a project for 5 and 6 floors with monolithic reinforced concrete frame. The structure has no irregularity in plan and in height.

The foundations of the structure are designed with two-stepped footing, with different dimensions (three types). Perimetral footings are connected to the head with prefabricated foundation beams, with dimensions (bxh) 300x400 $\mathrm{mm}$. All columns are located along the parallel axes, with dimensions $300 \times 400 \mathrm{~mm}$ (the amount of reinforcement is given in Figure 8). The transverse reinforcement (stirrups) is designed $\phi 6$, placed every $100 \mathrm{~mm}$ in critical zone and $200 \mathrm{~mm}$ in the mid-high of columns. The beams are designed with dimensions (bxh) $300 \times 400 \mathrm{~mm}$. Based on the technical design, the slabs are of prefabricated panels, with holes, $\mathrm{h}=110 \mathrm{~mm}$ (as shown in the Figure 7). 


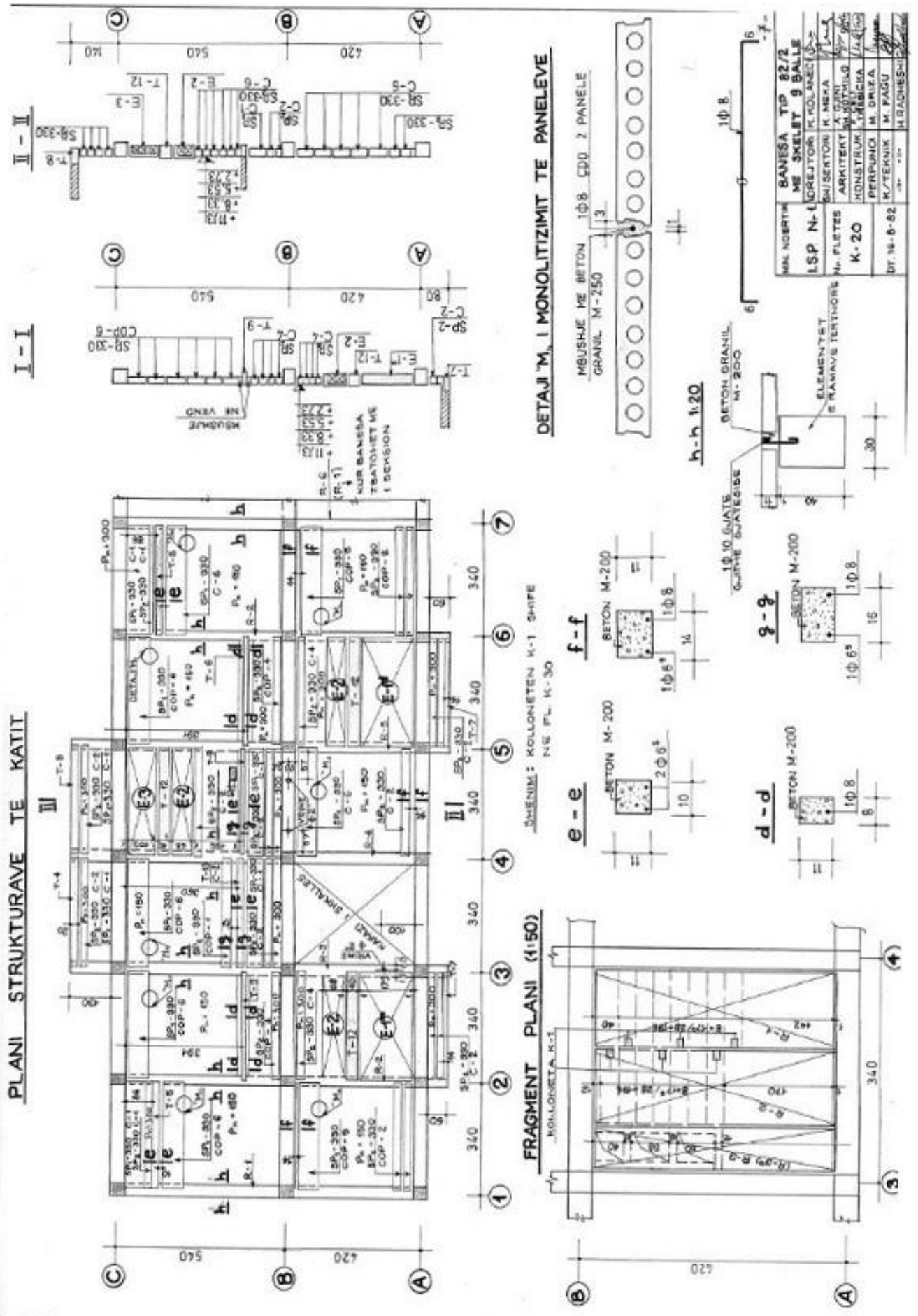

Fig. 5 Structural plan of building type 82/2 (one version), with prefabricated frames, as designed by Research and Design Institute No. 1 Tirana (ISP), (Central Technical Archive of Construction - AQTN) 


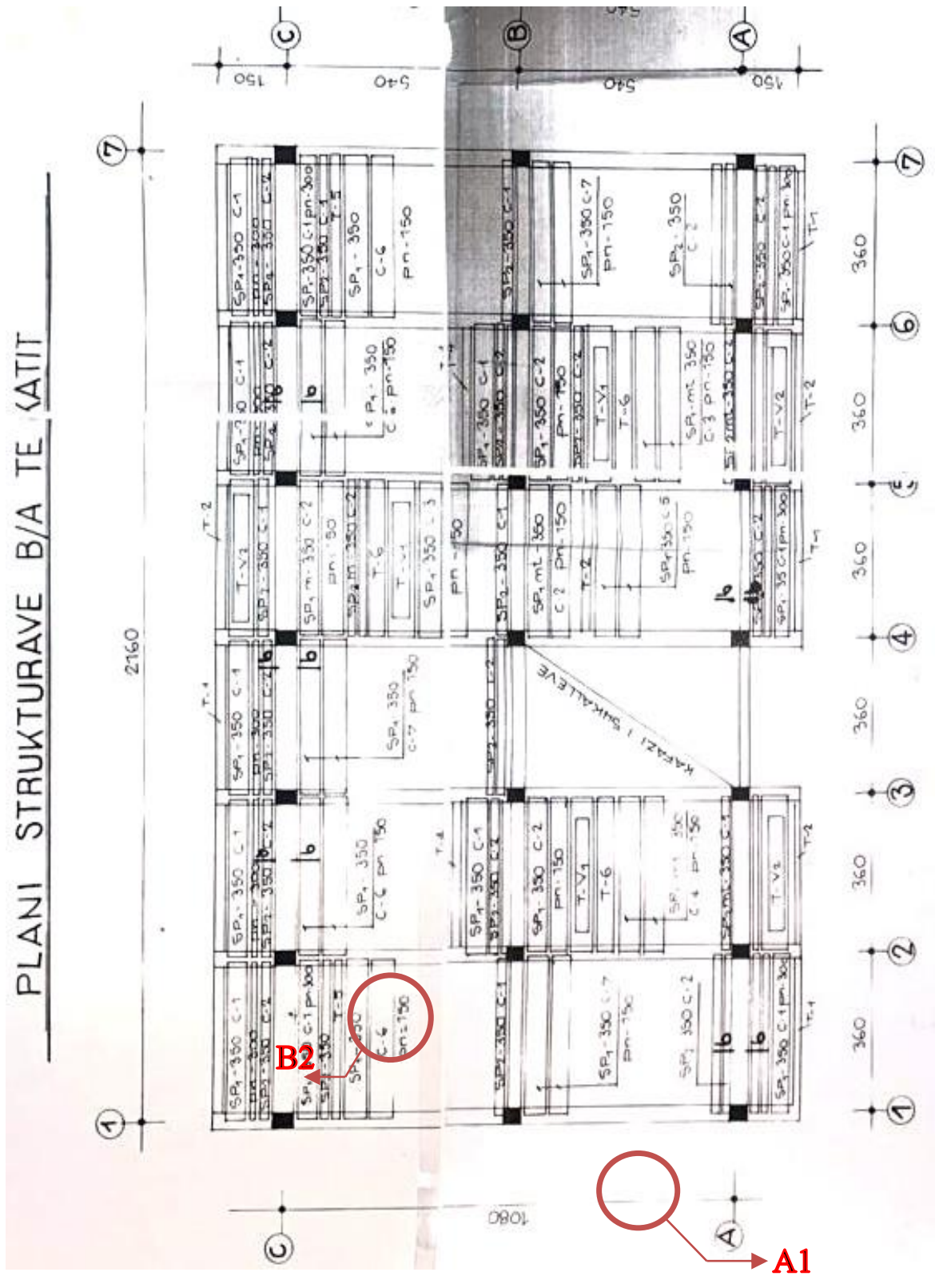

Fig. 6 Structural plan for building type 82/2, with monolithic RC frame system (as constructed) 

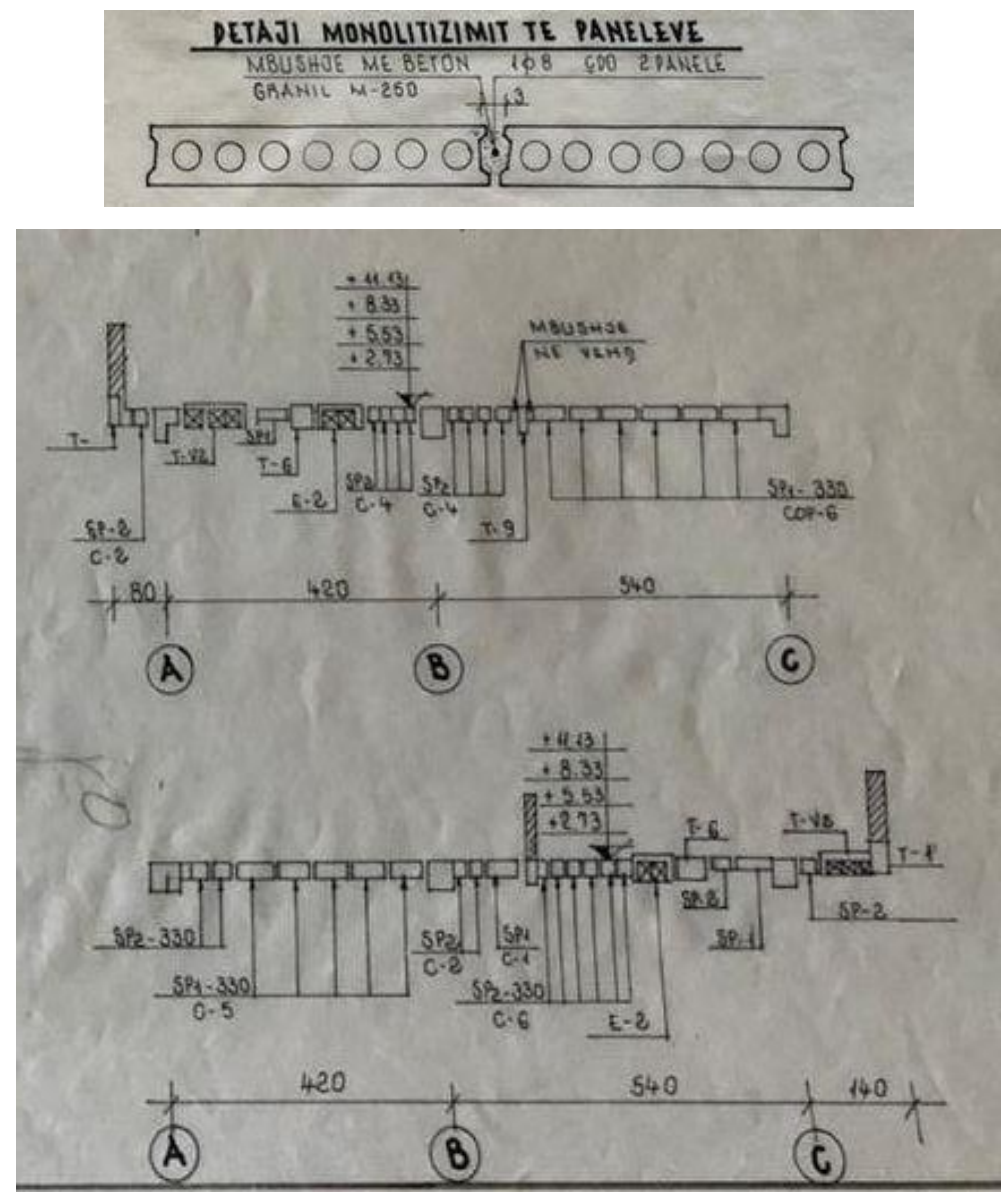

Fig. 7 Details of slabs (as constructed) 


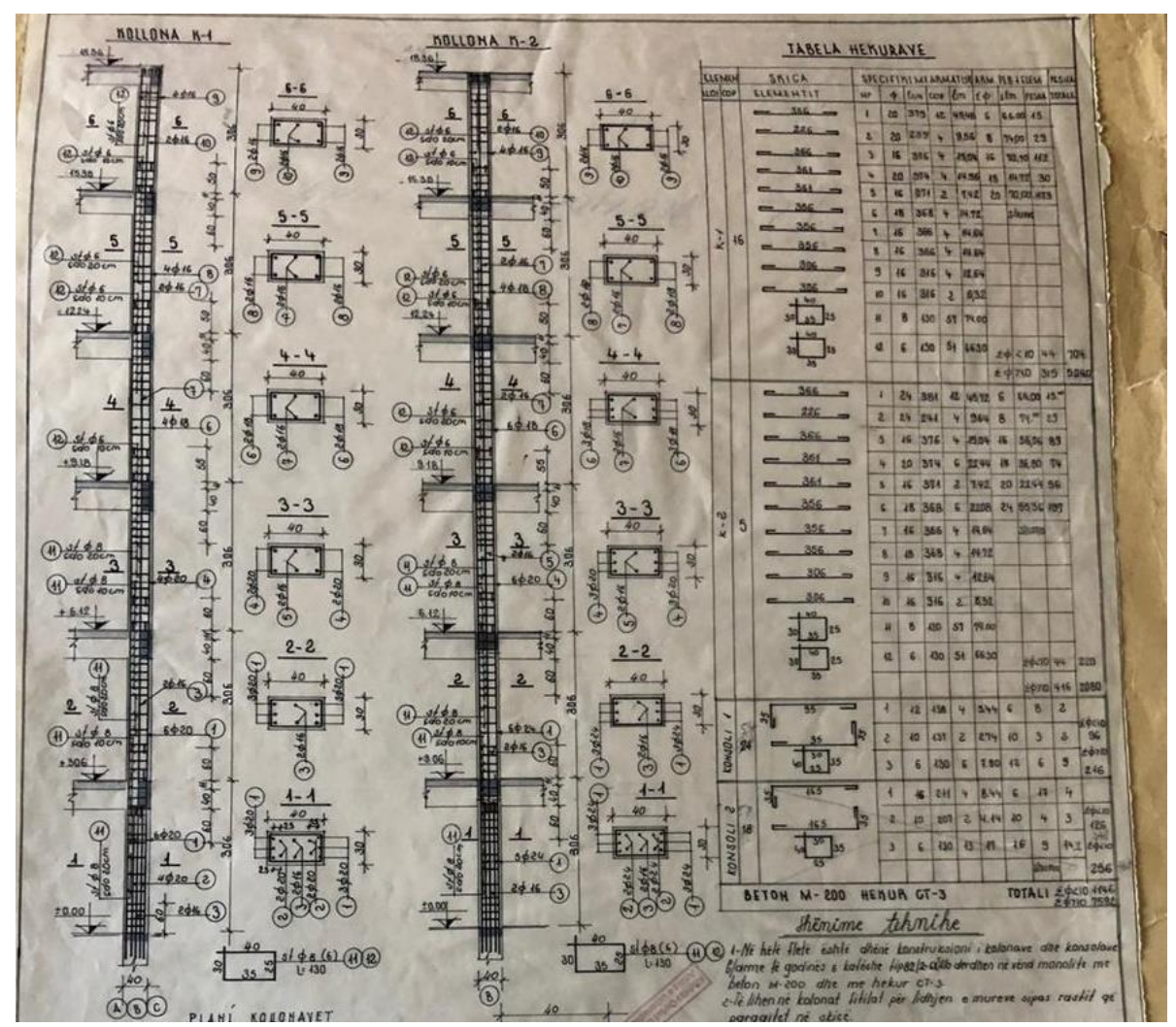

Fig. 8 Details for reinforcement of columns (as constructed)

\section{Location}

The buildings taken in the study are located in the city of Durrës, respectively in regions no. 3, 4 and 5. The area in which the buildings are positioned has a distance of about $22 \mathrm{~km}$ southwest from the epicenter of the November 26, 2019 earthquake.

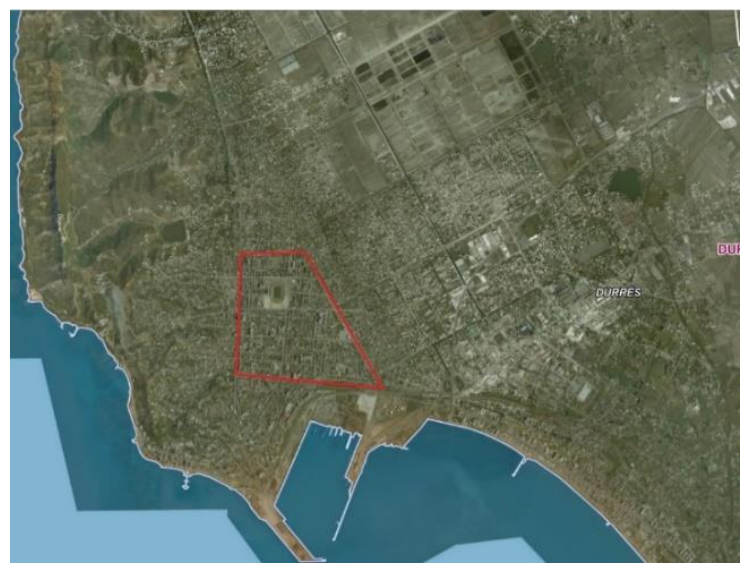

Fig. 9 Location of the studied buildings 


\section{Material Properties}

Referring to the technical notes in the structural design of the buildings type 82/2, the class of concrete is M-200 (C16/20), while reinforcing steel is Ç-3 (according to KTP-Albania design code). Below are given the characteristics of these materials.

Table 1. Properties of steel Ç-3

\begin{tabular}{cc}
\hline Characteristics of Reinforcing & \multicolumn{1}{c}{-3 } \\
\hline steel & $\mathrm{f}_{\mathrm{yk}}=250 \mathrm{MPa}$ \\
Characteristic yield strength & $\mathrm{f}_{\mathrm{tk}}=320 \mathrm{MPa}$ \\
Characteristic tensile strength & $\mathrm{E}_{\mathrm{s}}=210000 \mathrm{MPa}=210 \mathrm{GPa}$ \\
Modulus of elasticity & $\gamma_{\mathrm{s}}=1,15$ \\
Partial factor & $\mathrm{f}_{\mathrm{yd}}=215 \mathrm{MPa}$ \\
Design yield strength & $\mathrm{F}_{\mathrm{ywd}}=180 \mathrm{MPa}$ \\
Design yield for shear & $\mathrm{v}=0.30$ \\
Poisson's ratio & \\
\hline
\end{tabular}

Table 2. Properties of concrete C16/20

\begin{tabular}{|c|c|}
\hline Characteristics of concrete & $\mathrm{C} 16 / 20 \mathrm{MPa}$ \\
\hline Characteristic compressive cylinder strength & $\mathrm{f}_{\mathrm{ck}}=20 \mathrm{MPa}$ \\
\hline Characteristic cubic strength & $\mathrm{R}_{\mathrm{ck}}=16 \mathrm{MPa}$ (fck,cube) \\
\hline $\begin{array}{c}\text { Mean value of concrete cylinder compressive } \\
\text { strength ( } 28 \text { days) }\end{array}$ & $\mathrm{f}_{\mathrm{cm}}=28 \mathrm{MPa}$ \\
\hline Mean value of axial tensile strength of concrete & $\mathrm{f}_{\mathrm{ctm}}=2,2 \mathrm{MPa}$ \\
\hline Characteristic axial tensile strength of concrete & $\mathrm{f}_{\mathrm{ctk}}(5 \%)=1,5 \mathrm{MPa}$ \\
\hline Characteristic axial tensile strength of concrete & $\mathrm{f}_{\mathrm{ctk}}(95 \%)=2,9 \mathrm{MPa}$ \\
\hline Secant modulus of elasticity of concrete & $\mathrm{E}_{\mathrm{cm}}=30 \mathrm{GPA}$ \\
\hline $\begin{array}{c}\text { Design value of modulus of elasticity of } \\
\text { concrete }\end{array}$ & $\mathrm{E}_{\mathrm{cd}}=25 \mathrm{GPa}$ \\
\hline Partial factor for concrete & $\gamma c=1,5$ \\
\hline Design value of concrete compressive strength & $\mathrm{f}_{\mathrm{cd}}=\alpha^{*} \mathrm{f}_{\mathrm{ck}} / \gamma_{\mathrm{c}}=11,3 \mathrm{MPa}$ \\
\hline Poisson's ratio & $\mathrm{v}=0.20$ \\
\hline
\end{tabular}

For investigation purposes, concrete and steel samples were taken and laboratory tests were performed. From the tests performed in one of the building type $82 / 2$ (for the object shown in Figure 21) it results that the compressive strength of concrete samples is less than $50 \%$ of design requirements, and out of the requirements of KTP (Albanian design code), as shown in figure 10 . Whereas, the properties of the steel, from the laboratory tests, turn out to be acceptable according to the design definition and the technical conditions (Figure 11). 


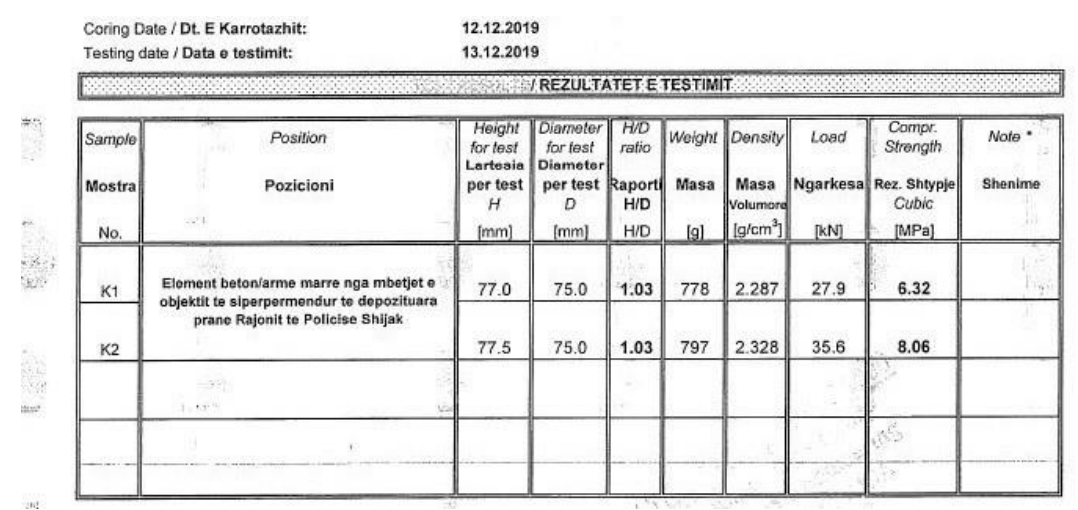

Fig. 10 Concrete test for one of the building type $82 / 2$

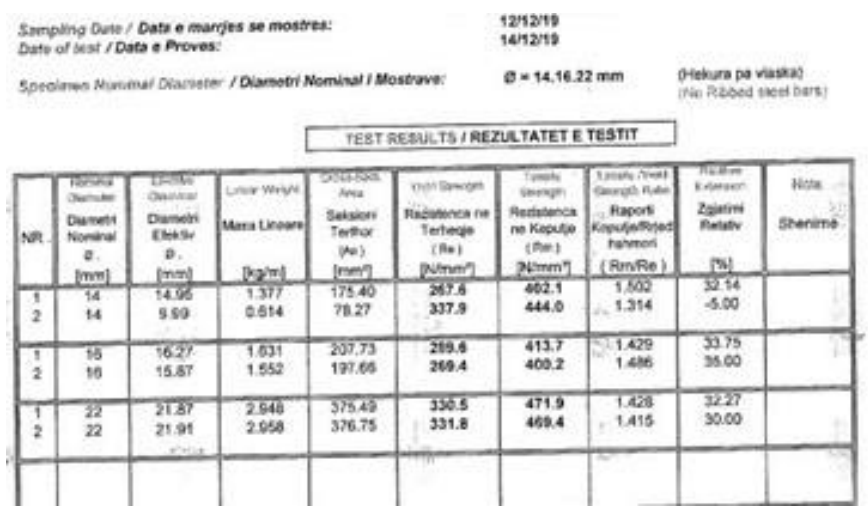

Fig. 11 Steel tests for one of the building type $82 / 2$

As can be seen in the figure 10 and 11, only few tests are performed, respectively 2 tests for the concrete and 6 for the steel (in unidentified elements).

Based on Eurocode 1998-3, for assessing the capacity of buildings, this number of tests and their position (the place where the tests were taken) are insufficient for the integral knowledge of the characteristics of these materials used in the structure. It is advisable to test materials for at least $20 \%$ of the structural elements when information on the project and construction of the work exists. In cases where this documentation is missing, the number of pieces of evidence should normally be increased [14].

For a reliable structural design of these structures, the proprieties of materials noted in the design papers are considered. From the field inspection (from authors) it was found that in one of the buildings defined for demolition, the concrete of the columns on the ground floor was spalled even with the lightest touch due to the use of sea sand and gravel with large fractions (Figure 12a). This phenomenon has also been influenced by the use of smooth rebar, which reduces the adhesion to concrete (Figure 12b). [15] 


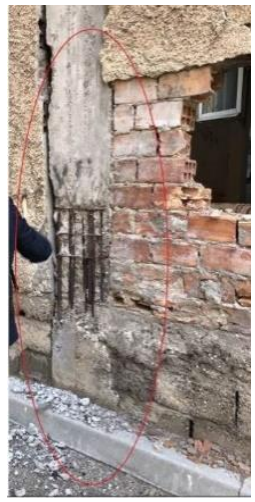

a)

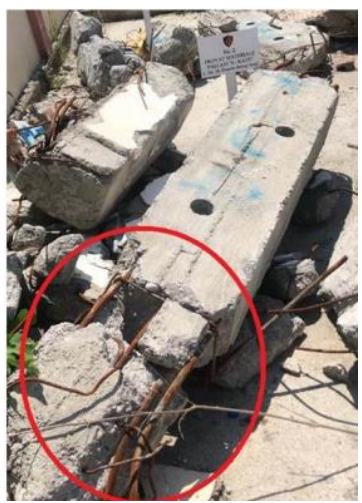

b)

Fig. 12 a) Spalling of concrete with hammer (photo by author), b) Smooth rebar for columns reinforcment (photo by author)

\section{Identification of Damages}

Before the year 1990, buildings are designed mainly based on the Albanian Technical Codes KTP-2-89 (which includes the seismic design norms).

The failure observed from Durrës Earthquake for various structures such as RC frame, brick masonry (clay/silicate) or prefabricated structures varied depending on the location, building type and the year of construction. The damages were evident in structural and non-structural elements. The key factors of RC frames damages can be listed:

- Design of high-rise buildings with reinforced concrete frame, without cores or diaphragms, as highly flexible structures with low rigidity. Damages have been identified in non-structural elements such as: out of plan walls, horizontal and diagonal cracks in the walls, etc.

- Differential settlement of the foundation due to the irregularity in plan and height, and seismic actions;

- Design of the structure with hidden beams in the slabs with smaller height, especially the perimetral beams, by reducing the stiffness of the structure.

- Incorrect design of stair beams by reducing the height of the columns and causing the effect of "short columns".

- Absence of piles, even when they are necessary for transmission of vertical forces and seismic action.

- Incorrect design of seismic joint in cases when two sections are built on the same foundation slab or pile, causing the effect of collision.

- Creation of plastic hinges in columns, due to their low strength compared to that of beams.

- Incorrect construction of beam-column joints.

Two of the studied buildings (type 82/2) collapsed, as a result of the earthquake of November 26, 2019, and the others have suffered significant damage to structural elements.

In Figure 13 damages of structural and non-structural elements are shown for various RC structures in Durrës city, taken during the field inspection. 


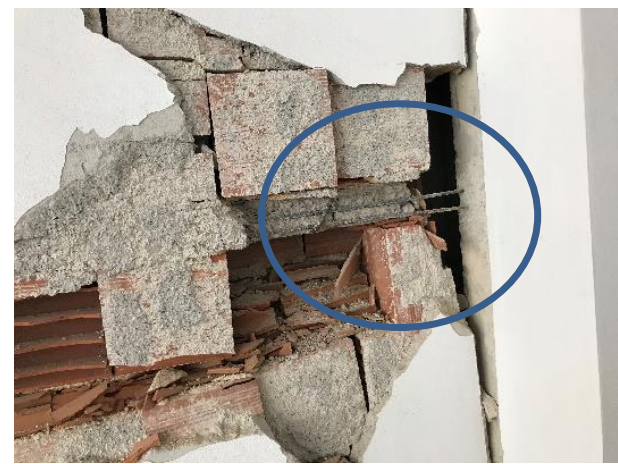

a) Out of plane wall failure (belt beams for infill walls are unlinked with RC columns)

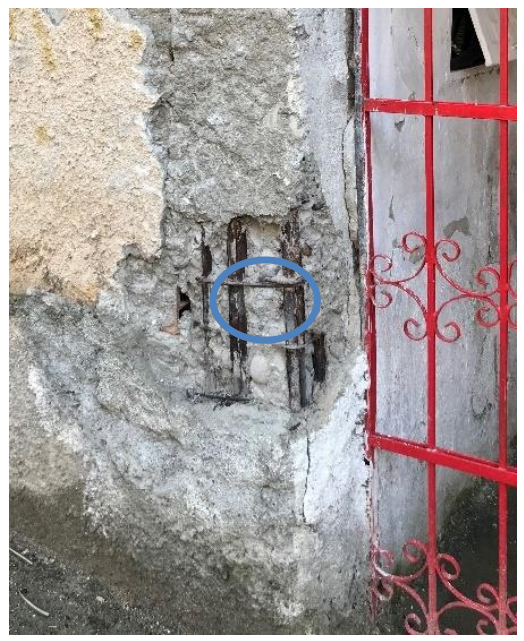

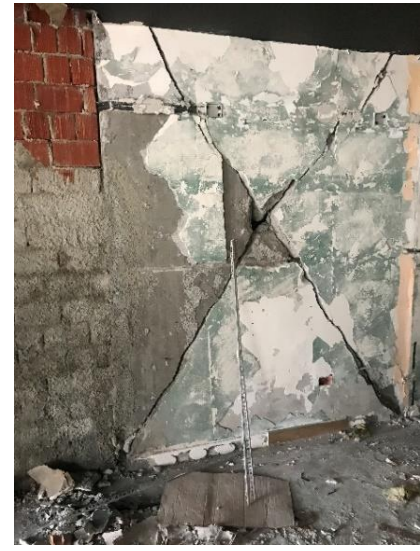

b) Failure of core type shear wall

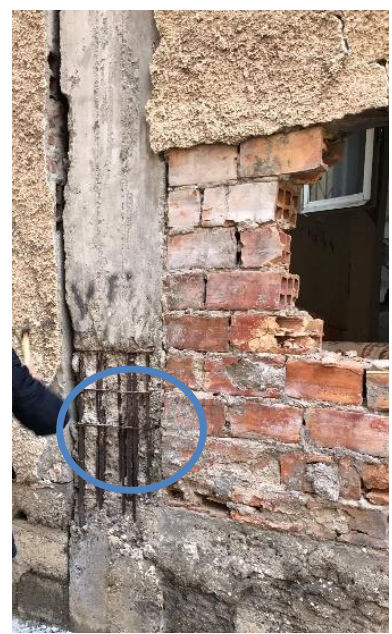

c, d) Longitudinal reinforcement not fastened by stirrup

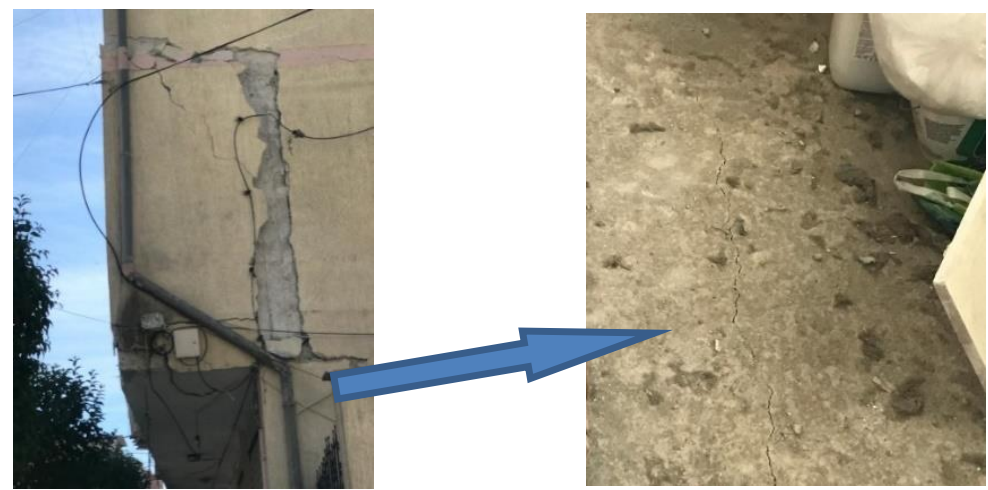

e, f) Deflection of the cantiliver beams (cracks in the slabs) 

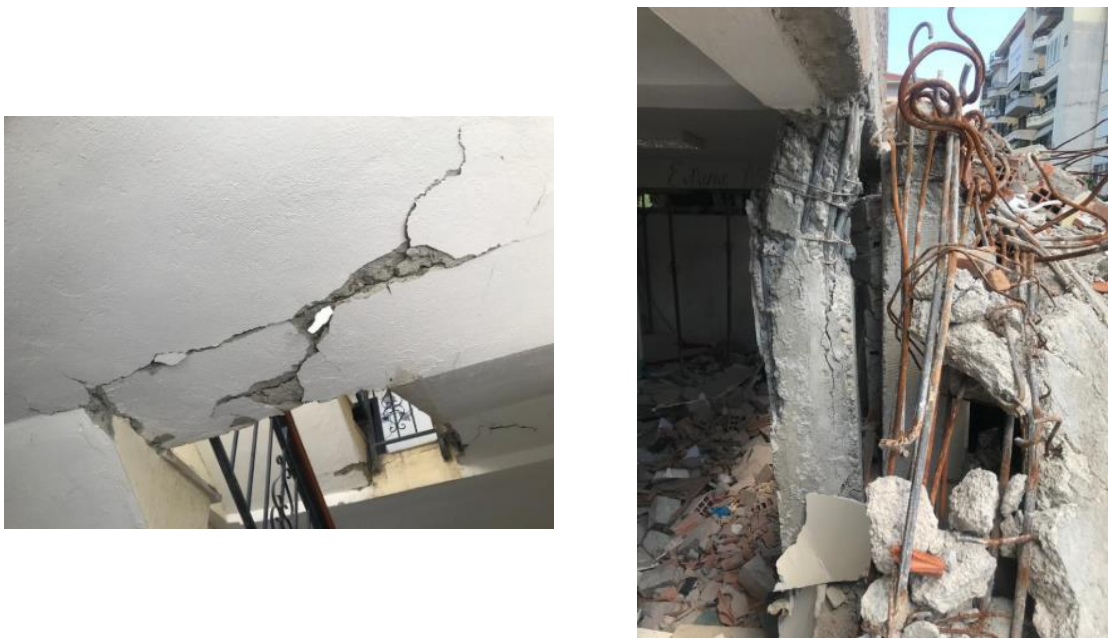

g) Cracks in the stair beam

h) Two buildings type $82 / 2$ near each other, the one on the left did not collapse and on the right totally collapsed
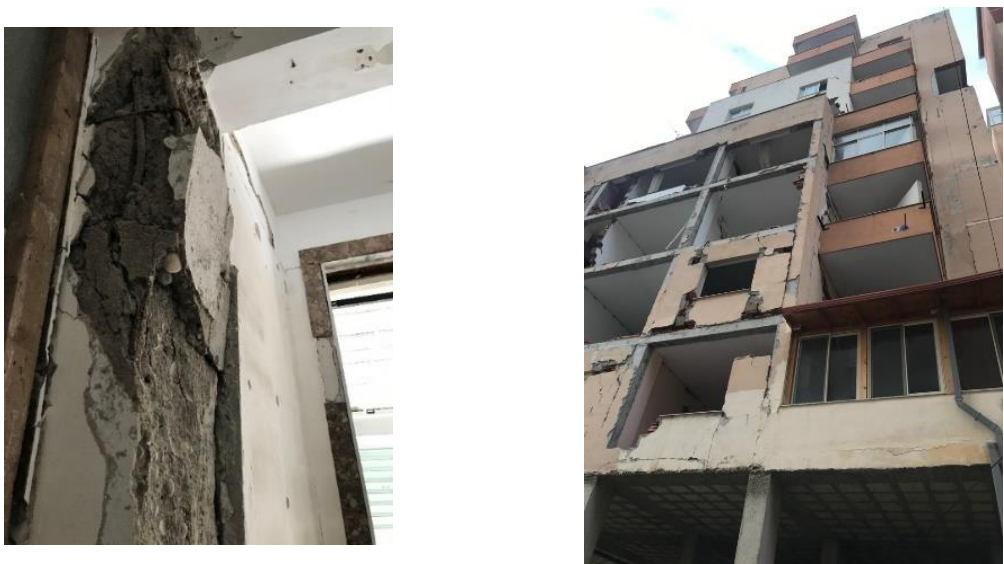

i) Plastic hinge in the upper part of column

j) Out-of-plane wall failure

Fig. 13 Photos of the various damaged buildings in Durrës city (photos by author)

\section{Model and Analysis}

The Type 82/2 structure is modeled with the ETABS Ultimate 19 software for two cases, for the 5 -storey building and the 6-storey building. The structure is modeled following the technical notes in the project. The model consists of 3D frame section, with slabs as shell elements. The proprieties of the materials are taken as described in section 5 (concrete and steel). Loadings (dead, live and earthquake) and their combination compliant with KTP-6-78 (Albanian design code) as follows: 


$$
\mathrm{S}_{\mathrm{v}}=\mathrm{S}_{\mathrm{g} 1}+0.8 \sum \mathrm{S}_{\mathrm{p} 1}+\mathrm{S}_{\mathrm{p} 2}
$$

where, $g_{1}$ - dead load, $p_{1}$-live loads, $\mathrm{p}_{2}$-earthquake

For the seismic loading is taken the spectra recorded in Durrës station during the earthquake of November 26, 2019, as shown in Figure 4 [12] . Live loads are applied as follows [16]:

- Apartment

$\mathrm{p}^{\mathrm{n}}{ }_{1}=150 \mathrm{daN} / \mathrm{cm}^{2}$

- Hallway

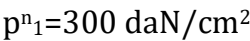

- Terraces

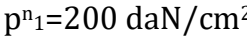

Using ETABS Ultimate 19 software [17], two types of analysis, namely, response spectrum analysis and non-linear static analysis (Pushover) are conducted. Also, the structure is modelled according Eurocode directives to estimate the amount of reinforcement required by this design code.

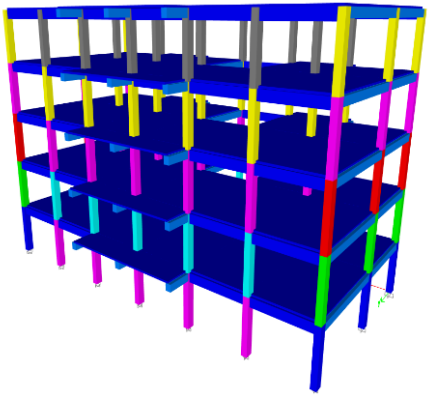

a)5 storey

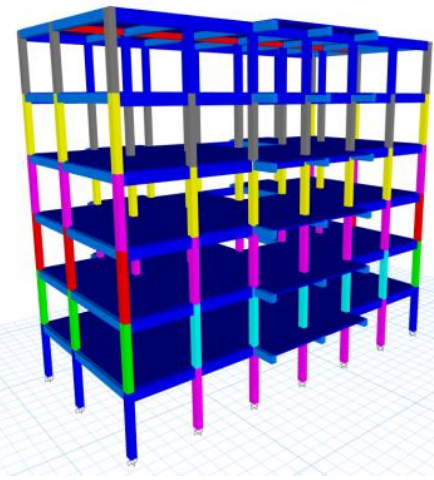

b) 6 storey

Fig. 14 Geometric models

\section{Results}

Below are shown the results obtained from the two types of analysis, response spectrum analysis and non-linear static analysis (Pushover). A very important parameter to assess the damage of structural and non-structural elements during seismic action, is the interstorey drift. 


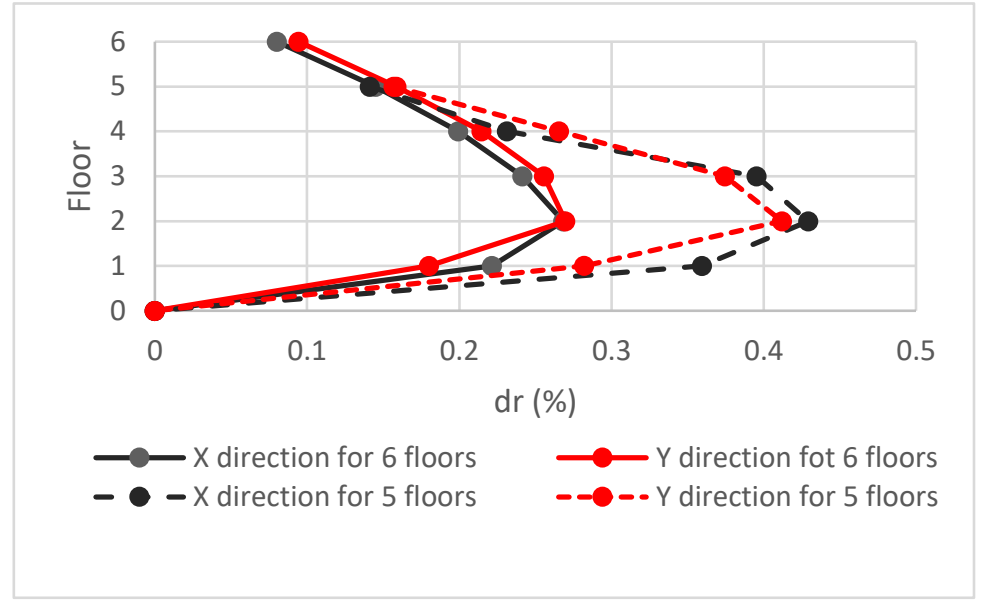

Fig. 15 Maximal drifts

As can be seen from the Figure 15, the interstorey drift reach up to 0.0043 for the 6 storey building and 0.0042 for the 5 storey building. For both studied cases, the requirement of EC-8 and KTP 89-2 are met (according to code maximum drift is 0.0087).

The interstorey drifts are higher in the $2^{\text {nd }}-3^{\text {rd }}$ floors because the amount of the columns reinforcement decreases. Referring to Figure 8, in the ground floor the columns are reinforced with $10 \phi 20+2 \phi 16$. In the first floor there is a reduction to $6 \phi 20+2 \phi 16(35.5 \%$ lower), and in the second floor (up to the last floor) it ends with 4\$20+2 $\phi 16(27.4 \%$ lower). While, the dimensions of the columns section do not change.

From the nonlinear static analysis (Pushover), the 5-storey building exhibits a seismic capacity that does not fulfill the seismic demand (for y-direction). This phenomenon is also evidenced in the 6-storey building (as shown in Figure 16 and 17).

$$
\text { Demand Idealized Capacity }
$$

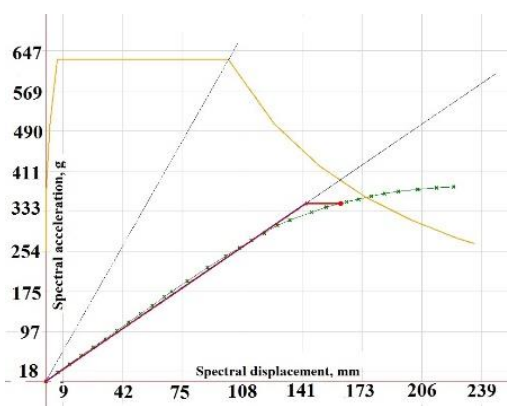

a) X-direction

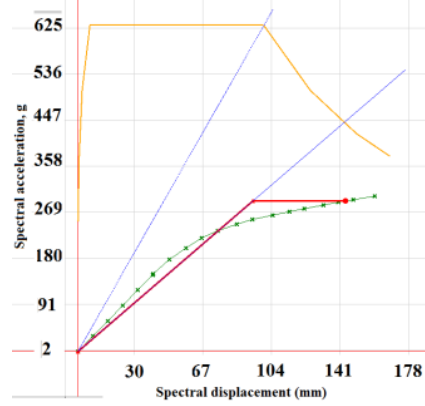

b) Y-direction

Fig. 16 Capacity diagrams for 5-storey building 


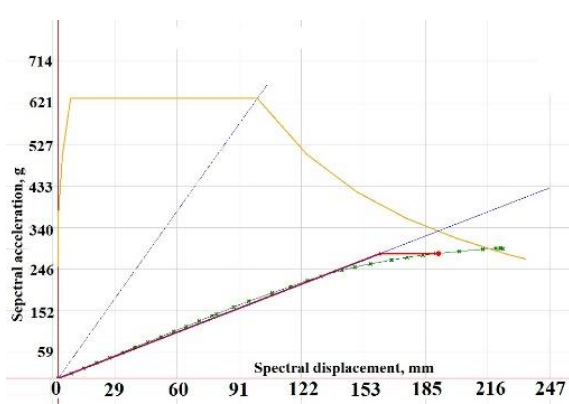

a) X-direction

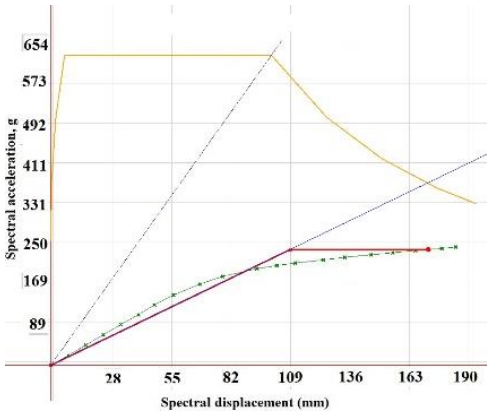

b) Y-direction

Fig. 17 Capacity diagrams for 6-storey building
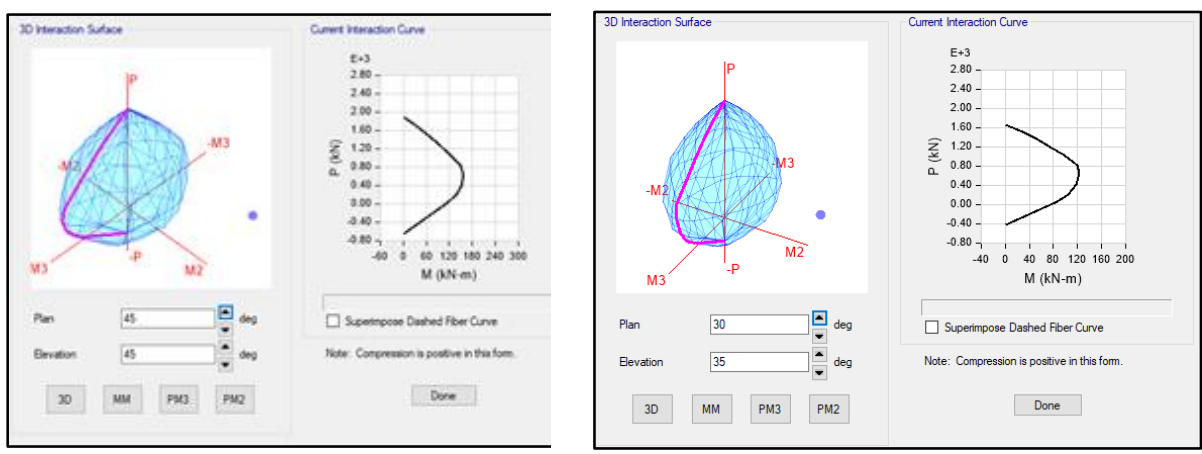

a) ground floor

b) first floor

Fig. 18 Interaction curves for column in axes A1 (specified in Fig.6) of 5-storey building

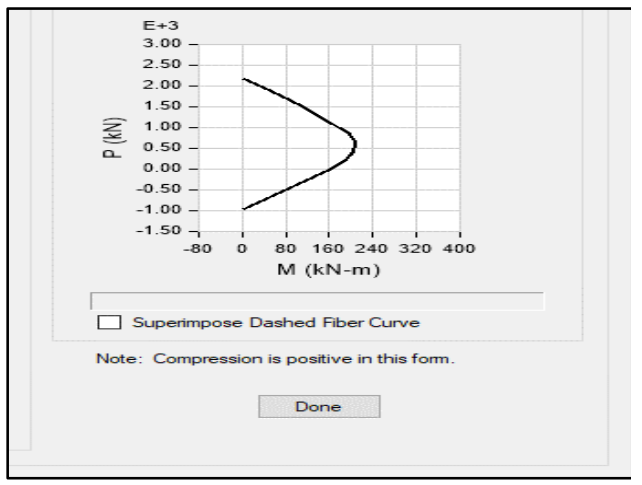

a) ground floor

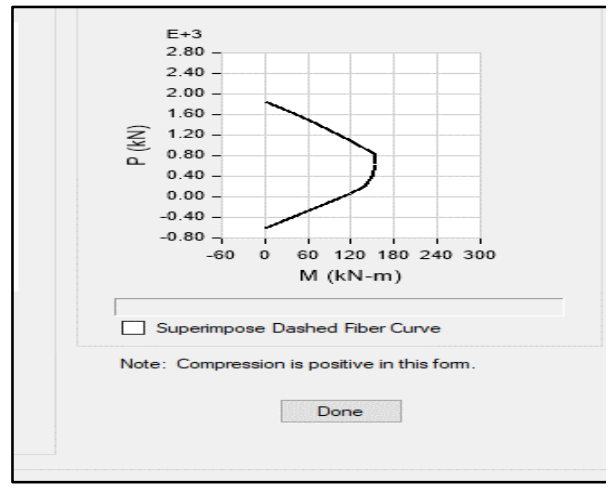

b) first floor

Fig. 19 Interaction curves for column in axes B2 (specified in Fig.6) of 5-storey building 
The P-M2-M3 interaction generated from response spectrum is represented by a point outside the interaction curve (Figs. 18 and 19). It is clear the reduction of the bending capacity of the ground floor and first floor columns also identified from the damaged state, with the appearance of plastic hinges at their ends. From the development of plastic hinges, it is evidenced that the expected mechanism of collapse develops on the first floor rather than ground floor (Figure 21). This is a reasonable explanation considering the immediate change in the quantity of the longitudinal reinforcement of columns on this floor.

The level of performance is described referring the corresponding damage limit state. In Figure 20, the force-deformation (moment-rotation) curve of a typical plastic hinge is given. Referring to Figure 22 (the plastic hinge distribution), for the 5 -storey building the plastic hinge is developed in the first floor, and corresponds to the point B (represents yielding) and in some elements to the point $\mathrm{E}$ (represents total failure). For the 6-storey building plastic hinges also develop in the first floor, representing by the point $\mathrm{C}$ (ultimate capacity) and $\mathrm{E}$ in some elements. Acceptance criteria for deformation or deformation ratios for primary members $(\mathrm{P})$ and secondary members $(\mathrm{S})$ corresponding to the target Building Performance Levels of Collapse Prevention (CP), Life Safety (LS), and Immediate Occupancy (IO) as shown in Figure 20, are given in FEMA 2000 [18].

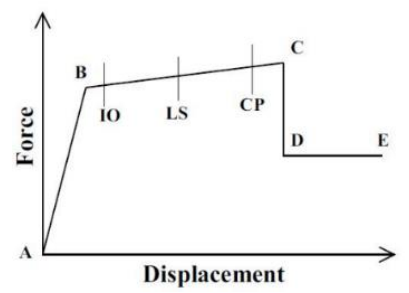

Fig. 20 Force-Deformation relationship of a typical plastic hinge [18]

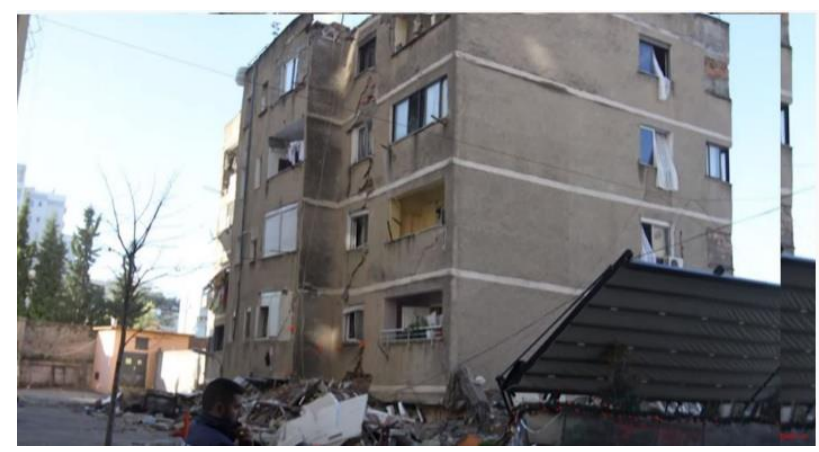

Fig. 21 Collapse of the first floor in 5 storey building type $82 / 2$ 

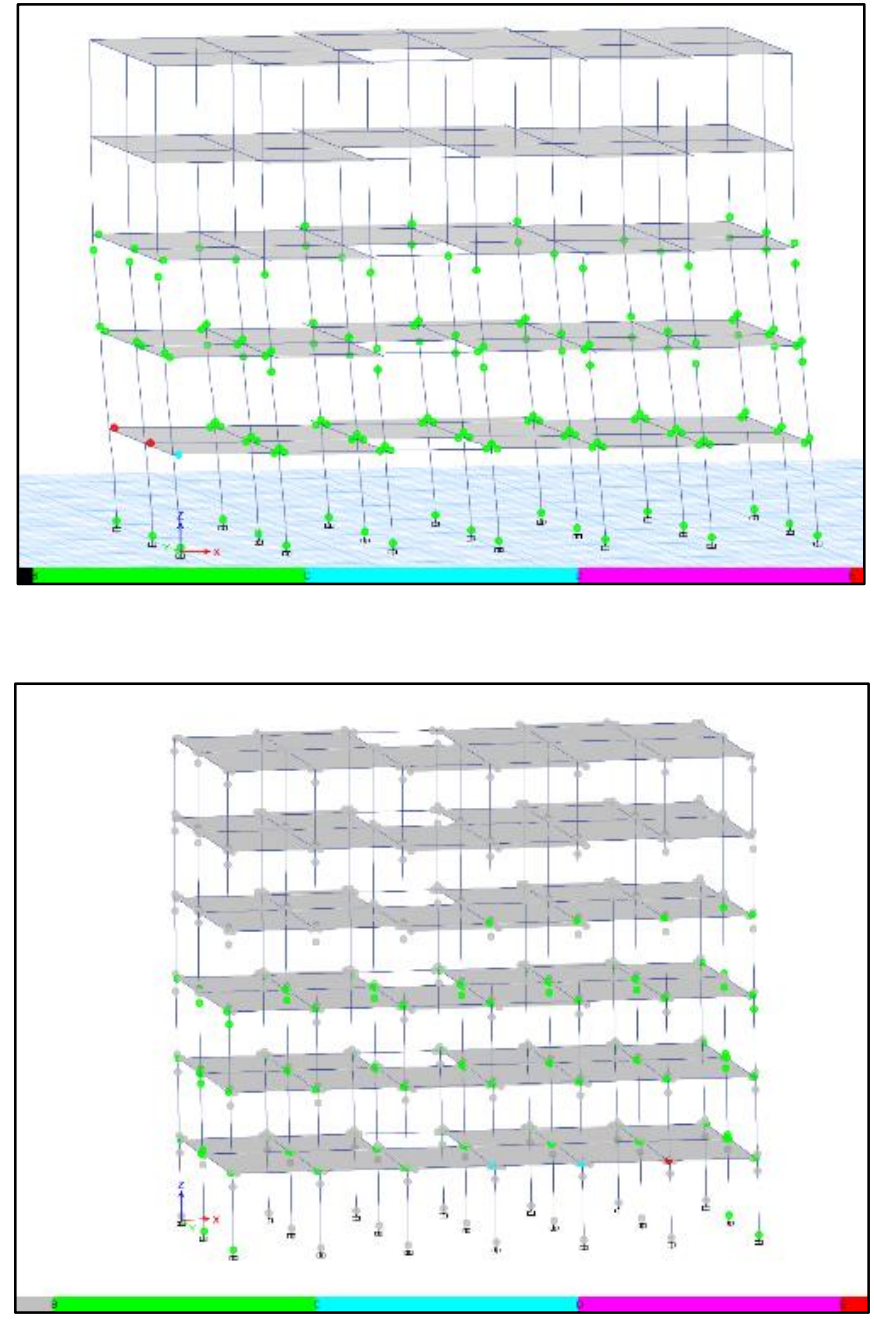

Fig. 22 Development of plastic hinges (generally in state A to B in plastic hinge development curve and a few in the highly plastic, near rupture D region ) from the nonlinear static analysis (Pushover) a) 5-storey and b) 6-storey building

Since ground floor columns in reinforced concrete structures are the most stressed elements during seismic action, in this study a comparison of reinforcement according to the project and structural modeling is made.

It is noticed that even for the 5 floor model, the amount of reinforcement required (obtained from response spectrum analysis) is greater than that referred to the project.

From the modeling of the project according to the current design codes such as Eurocode it can be seen that these elements (with the same concrete sections as given in the design papers) need very high reinforcement, respectively $5.88 \%$ and $6.96 \%(>4 \%)$ which is prohibited according to this code. 
Table 3. Comparison of reinforcement area and percentage (as-built project vs design model) for the two types of columns in the ground floor

\begin{tabular}{|c|c|c|c|c|}
\hline \multirow[t]{2}{*}{ \# } & \multicolumn{2}{|c|}{$\begin{array}{c}\text { 5-storey } \\
\text { Reinforcement (cm2) } \\
\text { Reinforcement }(\%) \\
\end{array}$} & \multicolumn{2}{|c|}{$\begin{array}{c}\text { 6-storey } \\
\text { Reinforcement (cm2) } \\
\text { Reinforcement (\%) }\end{array}$} \\
\hline & $\begin{array}{l}\text { As-build } \\
\text { project }\end{array}$ & $\begin{array}{l}\text { Design } \\
\text { model }\end{array}$ & $\begin{array}{c}\text { As-build } \\
\text { project }\end{array}$ & $\begin{array}{l}\text { Design } \\
\text { model }\end{array}$ \\
\hline $\mathrm{K}-1$ & $35.43(2.95 \%)$ & $\begin{array}{c}63.24 \\
(5.27 \%)\end{array}$ & $\begin{array}{c}35.43 \\
(2.95 \%)\end{array}$ & $\begin{array}{c}70.56 \\
(5.88 \%)\end{array}$ \\
\hline $\mathrm{K}-2$ & $\begin{array}{c}49.26 \\
(3.88 \%)\end{array}$ & $\begin{array}{c}76.20 \\
(6.35 \%)\end{array}$ & $\begin{array}{c}49.26 \\
(3.88 \%)\end{array}$ & $\begin{array}{c}83.52 \\
(6.96 \%)\end{array}$ \\
\hline
\end{tabular}

\section{Conclusion}

The purpose of this study is to analyze the behavior of the designed structure Type $82 / 2$, from the earthquake of November 26, 2019 in the city of Durrës, by comparing the results obtained from the response spectrum analysis (both for design of possible reinforcements and check of existing project) and non-linear static analysis (Pushover). The findings of the study can be stated as follows:

- Comparing the behavior of 5-storey and the 6-storey buildings results that they have the same collapse/failure mechanism.

- From the development of plastic hinges, it is evidenced that the expected collapse/failure mechanism develops on the first floor rather than the ground floor.

- The structural issues seem to be related to strength of elements, in the global and local level, rather than the displacement and drift related.

- $\quad$ For the 5-storey and 6-storey building, the percentage of reinforcement required for the given section exceeds the requirements of Eurocode 2 [19] and KTP by around $30 \%$, meanwhile provided reinforcement is around $56 \%$ of required reinforcement by design analysis. Hence, concrete section is insufficient to resist loading.

- The increase of the capacity ratio of the ground floor columns has affected the reduction of the bearing capacity of the structure of the 5 -storey building and even more with the addition of the sixth floor.

- The reinforcement area of columns is decreased in the first floor by $35.5 \%$ compared to the ground floor and in the second floor by $27.4 \%$ compared to the first floor. This explains the high interstorey drifts for the $2^{\text {nd }}-3^{\text {rd }}$ floor.

- There are some deficiencies that affected the low performance of this structure during the Durrës earthquake, causing damage to the load-bearing elements of these buildings. This fact is even more evident by considering the errors during construction, such as: use of transversal reinforcement with diameter and distance in critical zone that does not meet the requirements of design in seismic area, use of smoothed rebar as longitudinal reinforcement, or rather poor quality of the concrete used, justified on the conditions and quality of construction in the years when these structures were built (1983-1993). 


\section{References}

[1] "Earthquake Hazards Program," [Online]. Available: https://earthquake.usgs.gov/. [Accessed 30 November 2019].

[2] Republic of Albania, Council of Ministers, UNDP, "Albania Post-Disaster Needs Assessment Report," Council of Minister, Tirana, 2020.

[3] Freddi F, Novelli V, Gentile R, Veliu E, Andreev S, Andonov A, GrecoF, Zhuleku E. Observations from the 26th November 2019 Albania earthquake: the earthquake engineering field investigation team (EEFIT) mission, Bulletin of Earthquake Engineering, 2021, 19: 2013 - 2044. https://doi.org/10.1007/s10518-021-01062-8

[4] Isufi B, Ramos AP, Baballëku M. Seismic Behavior of Wide Beam - Column Connections: A Literature Review and Observations from the November 26, 2019 Durrës Earthquake, ISDEE-Interational Symposium on Durrës Earthquakes and Eurocodes, Tirana, 2020.

[5] Shkodrani N, Bilgin H, Hysenlliu M. Influence of interventions on the seismic performance of URM buildings designed according to pre-modern codes, Research on Engineering Structures and Materials, 2021, $7: 2 \quad 315 \quad-\quad 330$. https://doi.org/10.17515/resm2020.197ea0331

[6] Republika e Shqipërisë, VKM, "Për Realizimin e Ekspertizave të Thelluara për objektet e dëmtuara," Këshilli i Ministrave, Tirana, 2020.

[7] Bego M. Skeda arkitekture 1965-2004 në kronikën e një jete të dallgëzuar: mbi degradimin urban sot., Tirana: Dea, 2009.

[8] Bilgin H, Hysenlliu M. Comparison of near and far-fault ground motion effects on low and mid-rise masonry buildings, Journal of Building Engineering, 2020; 30: 101248. https://doi.org/10.1016/i.jobe.2020.101248

[9] "Institute of Statistics," [Online]. Available: http://instat.gov.al/al/temat/censet/censusi-i-popullsis\%C3\%AB-dhe-banesave/. [Accessed 2011].

[10] The European Union, EN 1998-1. Eurocode 8: Design of Structures for Earthquake Resistance - Part 1: General Rules, Seismic Actions and Rules for Buildings., CEN, 2004.

[11] Akademia e Shkencave, Ministraie Ndërtimit, Kusht Teknik Projektimi per Ndertimet Antisizmike KTP-2-89, Tirana, Albania: Akademia e Shkencave, 1989.

[12] "Instutite of Gjeosciences, Energy, Water and Evironment," [Online]. Available: https://www.geo.edu.al/newweb/?fq=bota\&gj=gj1\&kid=20.

[13] Duni L, Theodoulidis N. Short Note on the November 26, 2019 Durrës (Albania) M6.4 Earthquake: Strong Ground Motion with Emphasis in Durrës City, EMSC online report, 2019.

[14] The European Union, EN 1998-3 (2005) (English): Eurocode 8: Design of structures for earthquake resistance - Part 3: Assessment and retrofitting of buildings., CEN, 2005.

[15] Işık E, Harirchian E, Bilgin H, Jadhav $K$. The effect of material strength and discontinuity in RC structures according to different site-specific design spectra, Research on Engineering Structures and Materials, 2021. https://doi.org/10.17515/resm2021.273st0303

[16] Akademia e Shkencave, Ministria e Ndërtimit, "Kritere projektimi. Përcaktimi i ngarkesave në objektet shoqërore ekonomike", KTP-6-78, Tirana, Albania: Akademia e Shkencave, 1978.

[17] Computers and Structures INC. , Structural and Earthquake Engineering SoftwareETABS Ultimate 19, USA: Computers and Structures INC. , 2019.

[18] Federal Emergency Management Agency, Prestandard and Commentary for Seismic Rehabilitation of Buildings., Washington, D.C. : FEMA, 2000.

[19] The Europiean Union, Eurocode 2: Design of concrete structures - Part 1-1 : General rules and rules for buildings, CEN, 2004. 